\title{
Genetic and chemical diversity of native populations of Ocimum selloi Benth.
}

\author{
Roselaine Facanalia, ${ }^{\mathrm{a}}$, Carlos A. Colombo ${ }^{\mathrm{a}}$, João P.F. Teixeira ${ }^{\mathrm{a}}$, Lin C. Ming ${ }^{\mathrm{b}}$, \\ Maria I. Zucchi ${ }^{\mathrm{c}}$, Marcia O.M. Marques ${ }^{\mathrm{a}, *}$ \\ a Centro de PEDD de Recursos Genéticos Vegetais, Instituto Agronômico (IAC), Cx. Postal 28, CEP: 13001-970, Campinas, SP, Brazil \\ b Universidade Estadual Paulista Júlio de Mesquita Filho, Faculdade de Ciências Agronômicas, Departamento de Horticultura, Cx. Postal 237, CEP: \\ 18603-970 Botucatu, SP, Brazil \\ c Agência Paulista de Tecnologia dos Agronegócios, Polo Regional de Desenvolvimento Tecnológico do Centro Sul, Cx. Postal 28, CEP: 13400-970 Piracicaba, \\ SP, Brazil
}

\section{A R T I C L E I N F O}

\section{Article history:}

Received 25 February 2015

Received in revised form 15 June 2015

Accepted 19 June 2015

Available online 10 July 2015

\section{Keywords:}

Paregoric elixir

RAPD

Genetic diversity

Essential oil

\begin{abstract}
A B S T R A C T
The present work aimed to characterize the chemical composition of essential oils and genetic diversity of three native populations of Ocimum selloi collected in Brazil southern and southeastern. Thus, with the proposals to subsidize genetic improvement programs for the species preservation and commercial application of the essential oil.

A total of 60 samples from Iporanga and Piquete counties (State of São Paulo) and Adrianópolis county (State of Paraná) were analyzed by RAPD - genetic polymorphism - and GC-MS - chemical composition of essential oils. The data showed that the variation of the chemical composition of the essential oils of the samples was influenced by geographical region and genetic factors. The Piquete population was more homogeneous with respect to factors evaluated, and presented germacrene $\mathrm{D}$, elemicin, trans- $\alpha$ bergamotene, and bicyclogermacrene as the major components. Populations of Adrianópolis and Iporanga showed strong variability probably due to the gene flow between these populations, because they are geographically close. Most samples of these two regions had as major substances elemicin, $\beta$-selinene, and $\beta$-4-copaen- $\alpha$-ol. The results showed a great genetic and chemical divergence among and inside the populations between, being the diversity inside the populations bigger than among populations. The oils presented potential for commercial use in the manufacture of veterinary, pharmaceutical, and agricultural products.
\end{abstract}

(C) 2015 Elsevier B.V. All rights reserved.

\section{Introduction}

In Brazil, it is roughly estimated that there are 10,000 species of useful plants, medicinal, and aromatic ones, from the total of 55,000 species of superior plants that constitutes the various biomes of our flora (Amazon, Atlantic rain forest, Savannah, etc.). Many of theses species are source of income for the country (Nodari and Guerra, 2001). Ocimum selloi Benth. (sin. O. carnosum Link. et Otto) (Mentz et al., 1997), a native Lamiaceae plant occurring in southern and southeastern (Schmidt, 1858) commonly known as paregoric elixir, anise, small French basil, and 'Atroveran', is used in popular medicine as anti-diarrhea, anti-spastic, and anti-

\footnotetext{
* Corresponding author at: Av Barão de Itapura, 1481, Cx. Postal 28, Bairro Guanabara, Campinas, SP 13001-970, Brazil.

E-mail address: mortiz@iac.sp.gov.br (M.O.M. Marques).
}

inflammatory, properties that have been confirmed by pre-clinical tests (Nascimento et al., 2011), and other biological activities, such as antimicrobial, insecticidal, antioxidant, and analgesic (Franca et al., 2008; Ganiyu, 2008; Nascimento et al., 2011; Paula et al., 2003).

The analysis of the chemical composition of the essential oils from $O$. selloi obtained from two accessions ( $A$ and $B$ ) from the state of Minas Gerais, Brazil, carried out by Martins (1998), demonstrated that the major component for accession A was methyl chavicol (82\%: inflorescence; $81 \%$ : stem + leaves) and methyl eugenol for accession B (63\% for both). In contrast, Moraes et al. (2002), working with leaves from $O$. selloi harvested in the state of São Paulo in two seasons (winter: June/2000 and summer: January/2001), observed that the major substances of the essential oil were trans-anethole (45\% and 59\%, respectively) and methyl chavicol (24\% and 30\%, respectively), regardless of the season. Nascimento et al. (2011) reported that the main compounds found in the essential oil of $O$. 
selloi collected in Bahia were eugenol, 1,8-cineole, E-caryophyllene, and linalool, while Paula et al. (2003) reported the presence of methyl chavicol, trans-anethole, cis-anethole, and caryophyllene as major compounds of the essential oil of $O$. selloi collected in the district of Uvarana, city of Ponta Grossa in the state of Paraná. These compounds have a high commercial value and oils are used industrially in perfumery, cosmetics, and food as flavoring food (methyl chavicol, anethole, eugenol, and linalool) and pharmaceutical as anti-inflammatory and anesthetic for dental purposes (eugenol and caryophyllene) (Windholz, 1976; Craveiro et al., 1981; Pianowsky, 2005).

Essential oils are plant secondary metabolites, whose production is influenced by genetic, ontogenic, and environmental factors (Roberts et al., 1996). Currently, genetic structure and diversity information on natural populations are crucial for conservation and genetic improvement programs (Silveira et al., 2009).

Besides being a dominant marker, RAPD markers (random amplified polymorphic DNA) have been successfully used to analyze the genetic diversity of natural populations (Gomes Filho et al., 2010; Pessanha de et al., 2011; Troconis-Torres et al., 2012). For the studies of medicinal plants, we highlight the reports of Pluhár et al. (2012), with species of Thymus, Wang et al. (2011), with cultivations of Camellia, Silva et al. (2006), with Casearia sylvestris, Zucchi et al. (2005), with natural populations of Eugenia dysenterica, and Gaia et al. (2004), with Piper aduncum L. Even when, there are many reports using this marker for different species of Ocimum (Carović-Stanko et al., 2010; Chen et al., 2013; Chikkaswamy et al., 2013; Harisaranraj et al., 2008; Vieira et al., 2001, 2003), to our knowledge, $O$. selloi was not studied using it. O. selloi literature reports only one item of Amaral and Casali (2000) using isoenzyme marker for identification and characterization of populations of this species. The present work aimed to characterize the chemical and genetic diversity of three native populations. The biological properties and chemical composition of $O$. selloi the essential oil were also considered in order to evaluate potencial proposals to subsidize genetic improvement programs for the species preservation, through commercial application of the essential oil.

\section{Materials and methods}

\subsection{Plant material}

Aerial parts of 60 accessions of 0 . selloi were gathered in September 2002 (spring) in Iporanga county (20 accessions), October 2002 (spring) in Adrianópolis county (20 accessions), and July 2003 (winter) in the region of Piquete county (20 accessions) (Fig. 1). The sampling performed in this study was based on previous studies conducted by the authors with the essential oils of $O$. selloi plants because they showed that seasons can modulate the relative proportion on the chemical constituents, but they do not alter the major constituents (Moraes et al., 2002; Morais, 2003).

The region of Piquete was classified as Cwa (Köeppen) with average temperature of $21.3^{\circ} \mathrm{C}$, annual total rainfall of $1672.5 \mathrm{~mm}$ and dry and cold winter (average temperature $11^{\circ} \mathrm{C}$ ), distinct from the other two regions that was classified as Af (Köeppen) with average temperature of $23.6^{\circ} \mathrm{C}$, annual total rainfall of $2033.8 \mathrm{~mm}$ and winter with an average temperature of $20^{\circ} \mathrm{C}$ with no dry season (CEPAGRI/UNICAMP, 2013).

Plants collected in Iporanga and Adrianópolis were in vegetative and reproductive stage, while the collected in Piquete were in vegetative stage. The collected plants showed the following rates of flowering: Iporanga, 85\%, Adrianópolis, 75\%, and Piquete, $0 \%$, values compatible with sampling stations, i.e., spring and winter.
Exsiccates were deposited on the herbarium of Instituto Agronômico (State of São Paulo) and registered as IAC 42.949, IAC 44.396, and IAC 44.397. Five soil samples from each geographical region were collected for analysis of micro and macronutrients.

\subsection{RAPD analyses}

Sixty accessions of $O$. selloi were analyzed. Genomic DNA was obtained from fresh and healthy young leaves. The tissue samples were ground with in liquid nitrogen $\left(\mathrm{N}_{2}\right)$ and DNA extraction was performed in accordance with a modified CIMMYT protocol (Laboratory Protocols - CIMMYT Applied Molecular Genetics Laboratory). The DNA concentration was estimated on $0.8 \%$ agarose gel by comparison with known concentrations of $\lambda$ phage DNA $(20,60$, and $200 \mathrm{ng}$ ). After quantification, all samples were standardized to $10 \mathrm{ng} / \mu \mathrm{L}$ in TE solution for RAPD reactions.

Thirty-eight different primers of Operon Technology were tested, 22 of them being polymorphic (OPA18, OPAB03, OPAL09, OPB03, OPC08, OPF12, OPG05, OPH18, OPJ01, OPK11, OPK14, OPK15, OPL04, OPX01, OPX03, OPX04, OPX08, OPX17, OPX18, OPX20, OPY20, and OPZ09). The PCR reactions were performed as established by Williams et al. (1990) and Welsh and McClelland (1990), with small modifications with a final volume of $15 \mu \mathrm{L}$ containing: $5 \mathrm{pmol}$ of each primer (Operon Technology), $0.2 \mu \mathrm{L}$ of Taq-polymerase $(1 \mathrm{U}), 1.5 \mu \mathrm{L}$ of PCR buffer $10 \mathrm{X}, 0.9 \mu \mathrm{L}$ of dNTP $2.5 \mathrm{mM}, 0.75 \mu \mathrm{L}$ of $\mathrm{MgCl}_{2}$ [50 mM] and $3.0 \mu \mathrm{L}$ of DNA [30 ng], and Milli-Q water to complete the volume. The amplification reactions were carried out in a PT-100 model (MJ Research) thermocycler, with an initial step of DNA denaturation at $95^{\circ} \mathrm{C}$ for $5 \mathrm{~min}$, followed by 42 amplification cycles at $94^{\circ} \mathrm{C}(1 \mathrm{~min})$ - denaturation, $36^{\circ} \mathrm{C}(1 \mathrm{~min})$ - annealing, and $72^{\circ} \mathrm{C}(1.5 \mathrm{~min})$ - extension. After the 42 cycles the samples were submitted to a final extension step $\left(72{ }^{\circ} \mathrm{C}-7 \mathrm{~min}\right.$ ). The amplification products were submitted to $1.2 \%$ agarose gel electrophoresis to separate the fragments according to their molecular weight. As molecular weight marker, a $250 \mathrm{bp}$ ladder was used.

\subsection{Extraction and analysis of the chemical composition of essential oils}

The leaves of each accession of $O$. selloi were manually separated from the stems and dried at $40^{\circ} \mathrm{C}$ in an air-circulating oven to constant weight (about $48 \mathrm{~h}$ ). The essential oils were extracted by hydro-distillation in a Clevenger type apparatus during $1 \mathrm{~h} 30 \mathrm{~min}$.

The analysis of the chemical composition of the essential oils was carried in a GC-MS (Shimadzu, QP-5000), equipped with capillary column DB-5 (J\&W Scientific - Serial $\mathrm{N}^{\circ} 8766726$; $30 \mathrm{~m} \times 0.25 \mathrm{~mm}$, i.d., coating thickness $0.25 \mu \mathrm{m}$ ), in the following conditions: ionization voltage $70 \mathrm{eV}$; mass scan range: $35-450$ mass units; injector temperature $240{ }^{\circ} \mathrm{C}$; detector temperature: $230^{\circ} \mathrm{C}$; inject volume: $1 \mu \mathrm{L}$ split; ratio: $1: 30$; carrier gas: helium; flow rate: $1.7 \mathrm{~mL} \mathrm{~min}^{-1}$. The column temperature was programmed at $50^{\circ} \mathrm{C}$ isothermal for $5 \mathrm{~min}$, and then increased to $180^{\circ} \mathrm{C}$ at a rate of $5^{\circ} \mathrm{C} \mathrm{min}-1$ and then increased to $280^{\circ} \mathrm{C}$ at a rate a $10^{\circ} \mathrm{C} \mathrm{min}{ }^{-1}$. The identification of the substances was performed by comparison of their mass spectra against the database of the GC-MS (Nist. 62 Library), literature (Mclafferty and Stauffer, 1989), and retention indices (relative to C9-C25) (Adams, 2001).

\subsection{Statistical analysis}

The major compounds in the essential oil, data transformed to $\sqrt{ } x+1$, were compared among themselves and submitted to statistical analysis (MANOVA) by the software MINITAB ${ }^{\text {TM }}$ Statistical. The principal component analysis was performed using Numerical Taxonomy Multivariate Analysis System (NTSYS, version 1.70) 


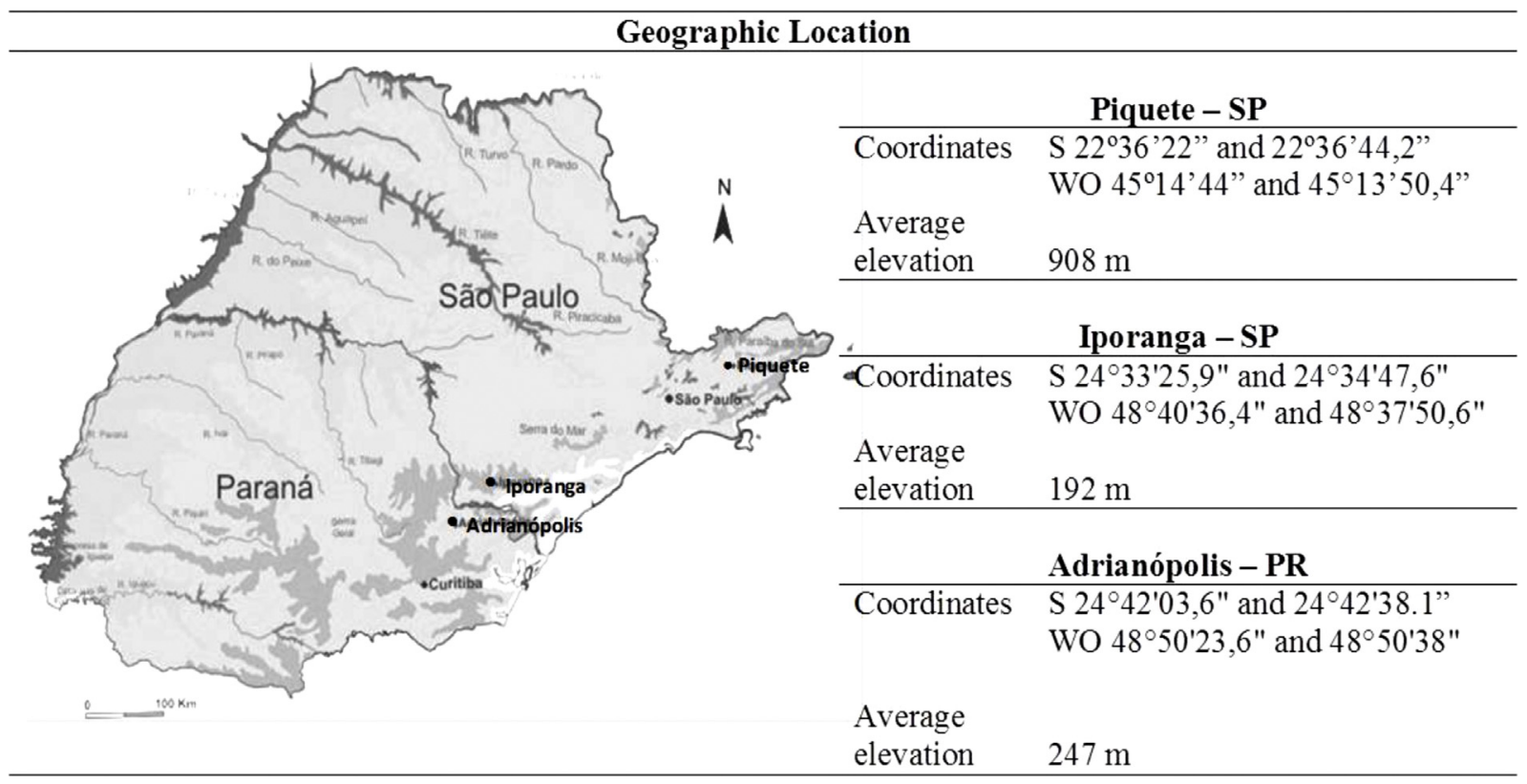

Fig. 1. Map of the states of São Paulo and Paraná, Brazil, showing the sampling sites of the Ocimum selloi Benth. accessions.

(Rohlf, 2000) and cluster analysis using the software XLSTAT - 2010 version (Addinsoft, France).

The bands, corresponding to the randomly amplified fragments, were evaluated as binary characters as presence (1) and absence (0). From this data, the genetic similarity degree was estimated among the accessions from the three sampled locations, using Dice similarity coefficient calculated by the software NTSYS (Rohlf, 2000). A dendrogram was built from the similarity analysis generated as described by Sneath and Sokal (1973), using the Unweighted Pair-Group Method, Arithmetic Average (UPGMA) method. The clustering stability or consistency was tested by random re-sampling, with 10.000 bootstraps, using the software BooD (Coelho, 2001). The variance analysis of the molecular data (AMOVA) was performed by total decomposition of its components among and within the populations using the square distances, as described by Excoffier et al. (1992) using the software Arlequin (Schneider et al., 2000).

\section{Results and discussion}

\subsection{Genetic diversity}

Among the 38 primers tested, 22 have produced good quality bands or amplification profile (Fig. 2). The molecular characterization of the 60 accessions of 0 . selloi was obtained from a total of 175 loci, from which 132 (76\%) were shown to be polymorphic. Genetic similarity for the 60 accessions, calculated by the Dice index, ranged from 0.33 to 1.00 , and the average values from the three sampled locations ranged from 0.60 to 0.85 .

Grouping analyses UPGMA have revealed the formation of clusters, showing that, except for groups A-D, the remaining clusters (E and F) exhibited no geographic structure, consisting of acces-
Table 2

Results of the pairwise difference by populations.

\begin{tabular}{llll}
\hline & Iporanga & Adrianópolis & Piquete \\
\hline Iporanga & 0.00000 & & \\
Adrianópolis & 0.17180 & 0.00000 & \\
Piquete & 0.47557 & 0.51413 & 0.00000 \\
\hline
\end{tabular}

sions from the same location as well as accessions from distinct geographic sites (Fig. 3).

According to Gauer and Cavalli-Molina (2000), the geographic distribution of a plant species greatly influences its level of genetic variability. Widespread species have been demonstrated to show superior genetic variation in comparison to the more restricted ones. It is due to the distinct selective pressures acting on species distributed in distinct environments. Species from geographically close locations normally present lower genetic divergence due to the possibility of gene flux among them.

The observed lower levels of genetic divergence among the accessions from Iporanga, state of São Paulo, and Adrianópolis, state of Paraná, are likely to be explained by the occurrence of gene flux between them. Analyzing AMOVA data, a highly significant $(P<0.001)$ molecular genetic diversity could be detected among the populations and within them. From the total molecular genetic variance found for the species, $41 \%$ is due to population divergence and $60 \%$, to within population divergence. The observed $\varphi_{\mathrm{ST}}$ value for 0 . selloi was $0.41(P<0.05)$, as shown in Table 1 . Pairwise $\varphi_{\mathrm{ST}}$ was lower between Iporanga and Adrianópolis (0.1718), and higher between Adrianópolis and Piquete (0.5141) (Table 2).

According to the AMOVA analysis, the genetic variation of the species $O$. sello i is represented by the intra-population variation. Several authors have investigated genetic variation in populations of several species, and have found results similar to those reported

Table 1

Results of the molecular variance analysis (AMOVA) for Ocimum selloi.

\begin{tabular}{|c|c|c|c|c|c|}
\hline VS & DoF & SQS & Total percentage of variation & $P$ & $\varphi$ Statistics \\
\hline Between populations & 02 & 462.7 & $40.6 \%$ & $(<0.001)$ & $\varphi_{\mathrm{ST}}=0.41$ \\
\hline Within populations & 57 & 898.8 & $59.4 \%$ & $(<0.001)$ & $1-\varphi_{\mathrm{ST}}=0.59$ \\
\hline TOTAL & 59 & 1361.4 & & & \\
\hline
\end{tabular}




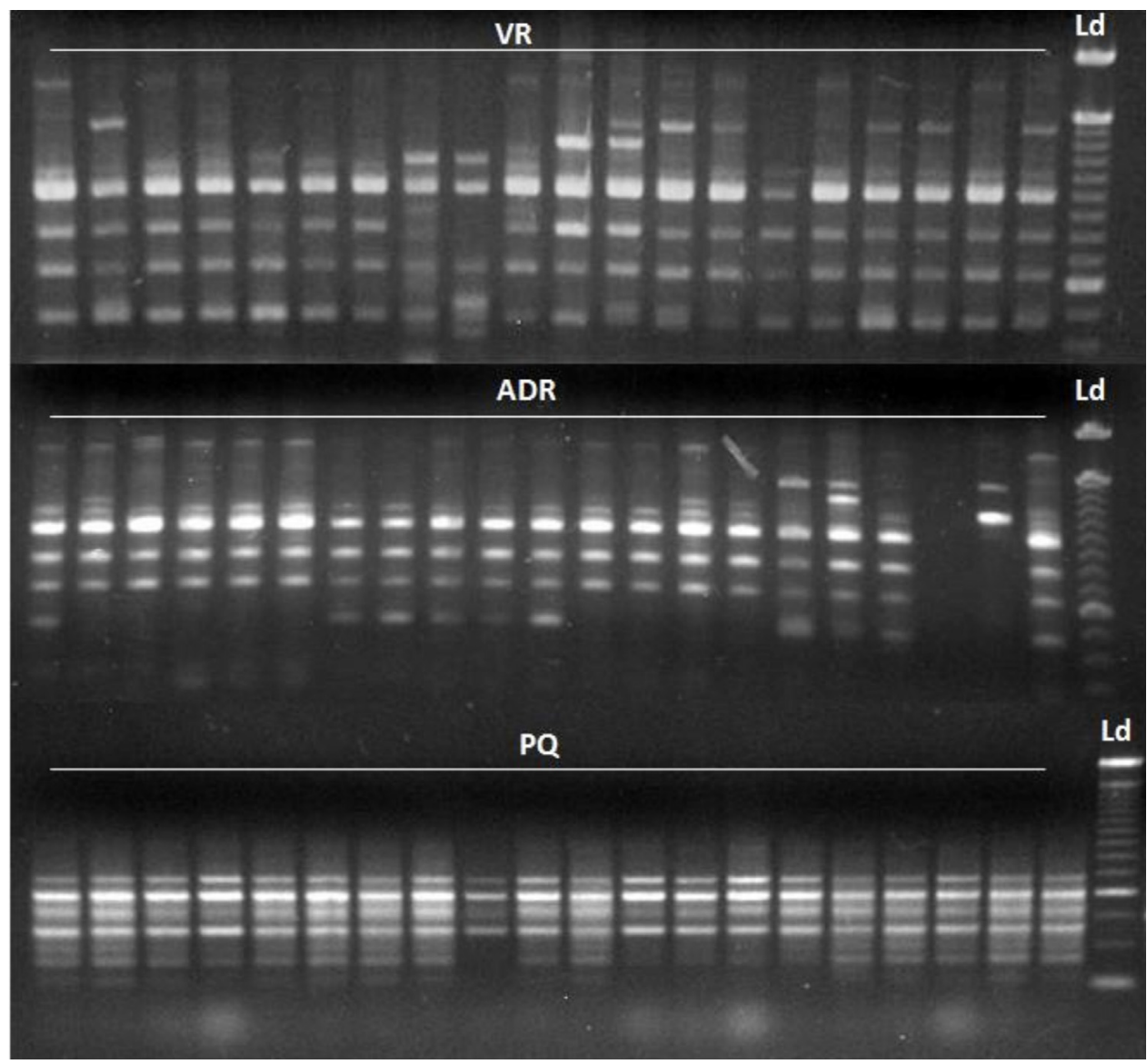

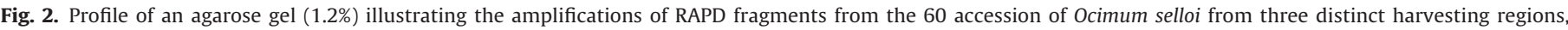
Iporanga/SP (VR), Adrianópolis/PR (ADR) and Piquete/SP (PQ); at the left (Ld) it is shown the molecular weight marker (Ladder 250 pb).

in our study. The distribution of the genetic diversity among and within the populations may be influenced by factors, such as the plant reproductive system, geographic distribution, dispersion mechanisms of pollen and seeds, natural selection, genetic drive, mutation rates, and life characteristics, such as founding effect, bottleneck effect, and anthropic interventions (Loveless and Hamrick, 1984).

The mating system of each species markedly affects the genetic composition of the populations. In general, outbreeding species exhibit high variability with highly polymorphic populations but showing lower divergence among populations when gene flux is allowed among them. Therefore, the majority of the diversity is concentrated within the population, in contrast to the observed for inbred species, where the majority of the variability is concentrated among the populations (Gauer and Cavalli-Molina, 2000). It is known from reproductive biology studies (Brasileiro and Amaral, 2007; Facanali et al., 2009), that O. selloi populations present mixed reproductive systems, presenting auto-fertilization, and out-crossing.

\subsection{Chemical composition of essential oils}

In the population from Iporanga, the class of phenylpropanoids represented $63.1 \%$ of the essential oil, whereas for the population from Piquete the sesquiterpenes hydrocarbons has predominated (75.2\%). The population from Adrianópolis presented the classes of sesquiterpenes hydrocarbons and phenylpropanoids, $43.0 \%$ and $39.8 \%$ of essential oil, respectively (Table 3 ). The population of Piquete was more homogeneous with respect to factors evaluated, and presented germacrene $\mathrm{D}$, elemicin, trans- $\alpha$-bergamotene and bicyclogermacrene as the major components. Populations of Adrianópolis and Iporanga showed strong variability probably due to gene flow between these populations, because they are geographically close. Most samples of these two regions had as major substances elemicin, $\beta$-selinene and $\beta$-4-copaen- $\alpha$-ol (Table 3 ). These results differ qualitatively from those obtained by Martins (1998), Moraes et al. (2002) and Paula et al. (2003), that found methyl chavicol, methyl eugenol, trans-anethole, eugenol, 1,8cineole, E-caryophyllene, and linalool, while the main compounds found in this study were sesquiterpene hydrocarbons in the population of Piquete, and elemicin in populations of Adrianópolis and Iporanga.

The MANOVA statistical analysis performed with the data of the the most abundant constituents of essential oils of leaves showed no significant differences due to the physiological stage of plants and the interaction between local and physiological stage.

However, the compounds of the essential oils have differed significantly according to the sampling sites, except for methyl chavicol, anethole, and methyl eugenol (Table 4). The variance analysis (Table 4) of the major components from the essential oils demonstrated a significant effect of the geographic location on the content of trans-caryophyllene, trans- $\alpha$-bergamotene, germacrene $\mathrm{D}, \beta$-selinene, bicyclogermacrene, $(E, E)-\alpha$-farnesene, elemicin and $\beta$-copaen-4- $\alpha$-ol.

It should be noted that data obtained for soil fertility has revealed no differences between the three sites, with no levels of limiting nutrients, however, significant differences between the study sites occur due to weather.

The region of Piquete, $908 \mathrm{~m}$ above sea level, was characterized by climatic condition related to the average temperature $\left(21.3^{\circ} \mathrm{C}\right)$, 


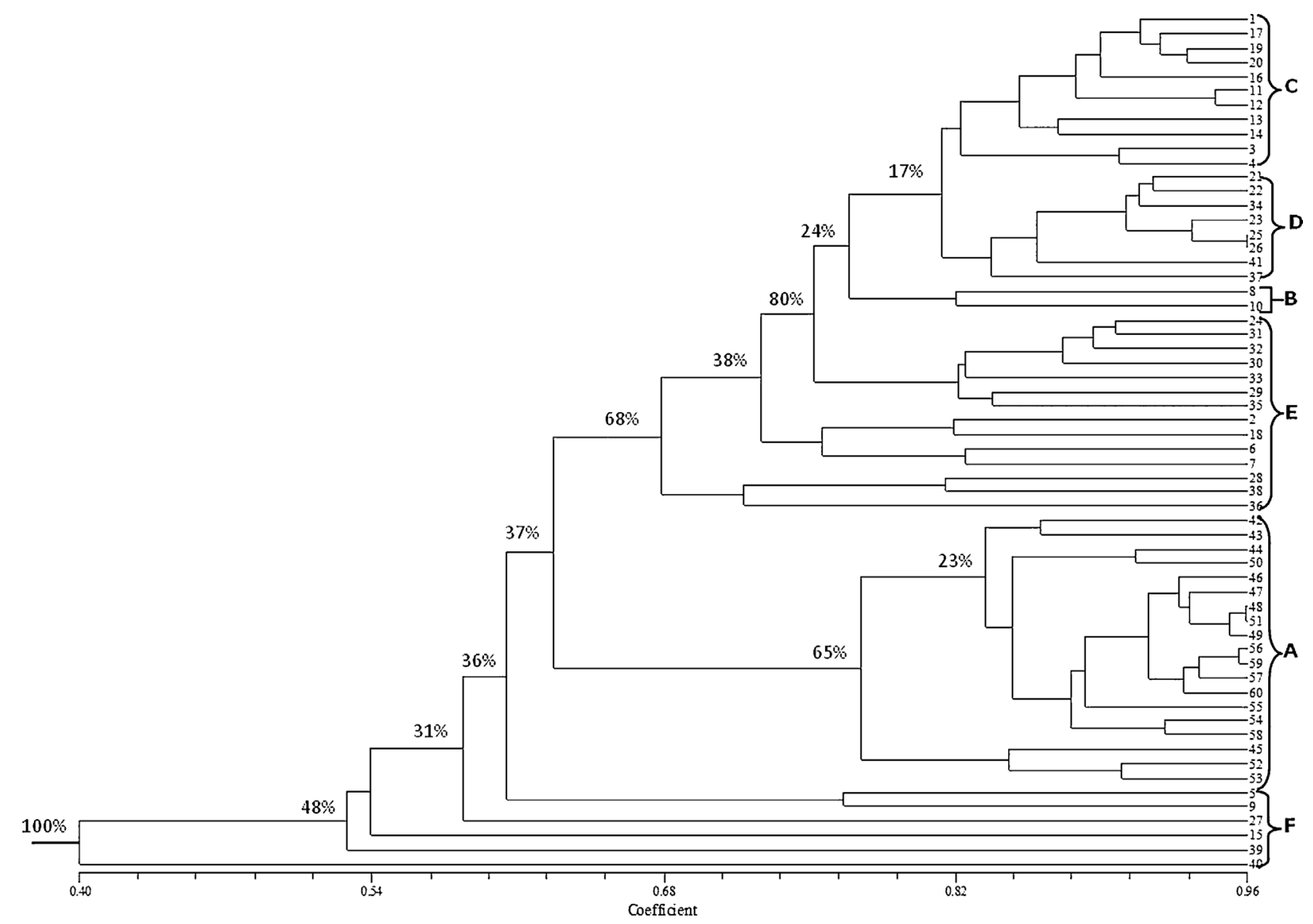

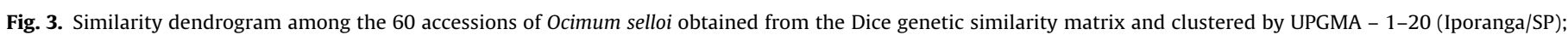
21-40 (Adrianópolis/PR); 41-60 (Piquete/SP).

annual total rainfall (1672.5 mm), and dry and cold winter (average $11^{\circ} \mathrm{C}$ ), distinct from the other two regions, Adrianópolis, $247 \mathrm{~m}$, and Iporanga, $192 \mathrm{~m}$ above sea level, which average temperature was $23.6^{\circ} \mathrm{C}$, annual total rainfall of $2033.8 \mathrm{~mm}$, winter with average temperature of $20^{\circ} \mathrm{C}$ with no dry season.

It should be noted that other authors describe the influence of genetic-environment interaction on the content of each constituent of essential oils of $O$. selloi as well as showed Moraes et al. (2002) and Morais (2003). These authors found, however, that the seasons did not affect the main components of essential oils. A study conducted with the essential oils of $O$. selloi plants, of occurrence in Botucatu (state of São Paulo), collected in winter 2000 (June) and summer 2001 (January), showed that seasons can modulate the relative proportion on the chemical constituents, but they do not alter the major constituents, keeping trans-anethol as the most abundant substance followed by methyl chavicol (Moraes et al., 2002). From January 2001 to January 2003, Morais (2003) made further study that aimed at characterizing the chemical composition of essential oils from leaves O.selloi plants obtained from the access evaluated by Moraes et al. (2002) and cultivated in Botucatu, depending on the seasons: spring (December 2001, September 2002), winter (July 2002), autumn (April 2002), summer (January 2003). As in the previous study, the major constituent was trans-anethol followed by methyl chavicol throughout the seasons. These results emphasize the importance of genetic factors in the chemical phenotype of essential oil of $O$. selloi.

The information presented may be summarized as follows: the data obtained for the three populations reveals that different chemical composition of essential oils were not due to intrinsic factors of plants, such as physiological state, nor the conditions of soil fertility, but the interaction genotype and environmental factors related to the different climatic conditions of the studied sites, altitude, average temperature, rainfall, average temperature and rainfall in winter, that differentiate Piquete region from the other two locations, Iporanga and Adrianópolis.

The principal component analysis (PCA) applied to the eleven main compounds of essential oil of the 60 accessions of $O$. selloi, expressed $58.73 \%$ of the total chemical variation in the first two principal components and indicated the separation of access from three locations into four groups established from the following major components: (A) methyl chavicol and trans-anethole, formed by accessions of Iporanga and Adrianópolis; (B) methyl eugenol formed by accessions of Iporanga and Piquete; (C) germacrene D, trans- $\alpha$-bergamotene, bicyclogermacrene and $(E, E)$ - $\alpha$-farnesene, formed by accessions of Piquete, and (D) elemicin, $\beta$-selinene and $\beta$-copaen-to-4-ol, formed by accessions of Adrianópolis and Iporanga (Fig. 4). Similar results were obtained by cluster analysis based on the chemical composition of essential oils. The dendrogram was built through the analysis of Cluster from the similarity matrix (Pearson correlation coefficient) showed four main groups (A-D) containing sixty accessions of 0 . selloi. According to Fig. 5 , cluster A, represented by two accessions from Iporanga population and one access from Adrianópolis population (VR10, VR12 and ADR16), was characterized by a high content of methyl chavicol and trans-anethole (Fig. 6). The cluster B with two accessions, from Iporanga population and Piquete population (VR8 and PQ18) was characterized by high levels of methyl eugenol. The groups $C$ and $\mathrm{D}$ are sub-divided in three and two sub-groups, respectively 
Table 3

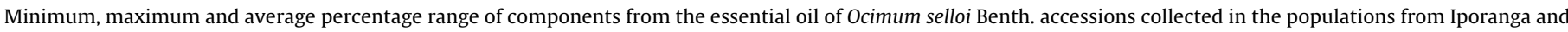
Piquete (SP), and Adrianópolis (PR), Brazil.

\begin{tabular}{|c|c|c|c|c|c|c|c|c|c|c|}
\hline \multirow[t]{2}{*}{ Components } & \multirow[t]{2}{*}{ RI } & \multicolumn{3}{|c|}{ Iporanga (\%) } & \multicolumn{3}{|c|}{ Adrianópolis (\%) } & \multicolumn{3}{|c|}{ Piquete (\%) } \\
\hline & & Min & Max & Avg $^{\mathrm{a}}$ & Min & Max & Avga & Min & Max & $\operatorname{Avg}^{\mathrm{a}}$ \\
\hline trans- $\beta$-Ocimene & 1046 & - & 0.6 & 0.1 & - & 1.7 & 0.4 & - & 1.5 & 0.3 \\
\hline Methyl chavicol & 1197 & - & 35.2 & 3.5 & - & 46.0 & 2.3 & - & - & - \\
\hline trans-Anethole & 1283 & - & 17.3 & 1.6 & - & 26.5 & 1.3 & - & - & - \\
\hline$\delta$-Elemene & 1339 & $\operatorname{tr}$ & $\operatorname{tr}$ & $\operatorname{tr}$ & - & 0.7 & 0.2 & $\operatorname{tr}$ & 2.1 & 0.6 \\
\hline$\alpha$-Copaene & 1376 & - & 3.4 & 2.1 & - & 4.6 & 2.8 & 0.8 & 2.7 & 1.9 \\
\hline$\beta$-Bourbonene & 1385 & - & 2.7 & 1.0 & - & 3.4 & 0.9 & 0.7 & 2.3 & 1.5 \\
\hline$\beta$-Cubebene & 1390 & $\operatorname{tr}$ & $\operatorname{tr}$ & $\operatorname{tr}$ & $\operatorname{tr}$ & $\operatorname{tr}$ & $\operatorname{tr}$ & $\operatorname{tr}$ & 1.0 & 0.6 \\
\hline$\beta$-Elemene & 1392 & $\operatorname{tr}$ & $\operatorname{tr}$ & $\operatorname{tr}$ & - & 0.9 & 0.4 & 0.4 & 1.4 & 0.8 \\
\hline Methyl eugenol & 1403 & - & 40.8 & 3.2 & - & - & - & - & 54.3 & 3.5 \\
\hline trans-Caryophyllene & 1419 & - & 5.3 & 2.6 & - & 11.2 & 6.1 & 1.6 & 5.6 & 3.9 \\
\hline trans- $\alpha$-Bergamotene & 1436 & - & 3.9 & 1.7 & - & 3.7 & 1.0 & 11.2 & 20.6 & 15.1 \\
\hline$\alpha$-Guaiene & 1440 & - & - & - & - & - & - & 0.1 & 3.5 & 1.5 \\
\hline$\alpha$-Humulene & 1453 & $\operatorname{tr}$ & $\operatorname{tr}$ & $\operatorname{tr}$ & - & 0.5 & 0.2 & $\operatorname{tr}$ & 1.5 & 0.8 \\
\hline Seychellene & 1457 & $\operatorname{tr}$ & $\operatorname{tr}$ & $\operatorname{tr}$ & - & 0.1 & $\operatorname{tr}$ & $\operatorname{tr}$ & 0.8 & 0.4 \\
\hline Allo-aromadendrene & 1460 & $\operatorname{tr}$ & $\operatorname{tr}$ & $\operatorname{tr}$ & $\operatorname{tr}$ & $\operatorname{tr}$ & $\operatorname{tr}$ & $\operatorname{tr}$ & 1.0 & 0.6 \\
\hline Germacrene D & 1480 & $\operatorname{tr}$ & 16.5 & 6.3 & - & 17.9 & 8.0 & 12.2 & 38.6 & 25.7 \\
\hline$\beta$-Selinene & 1487 & 1.1 & 17.0 & 7.9 & - & 25.0 & 11.1 & 0.2 & 4.2 & 1.9 \\
\hline Bicyclogermacrene & 1495 & $\operatorname{tr}$ & 6.6 & 4.2 & - & 11.9 & 7.2 & 4.8 & 20.0 & 12.3 \\
\hline$(E, E)-\alpha$-Farnesene & 1508 & $\operatorname{tr}$ & 2.8 & 1.4 & - & 6.2 & 2.6 & 0.9 & 8.3 & 3.8 \\
\hline 7-epi- $\alpha$-Selinene & 1517 & - & - & - & - & - & - & - & 4.0 & 1.6 \\
\hline$\delta$-Cadinene & 1523 & - & 3.6 & 1.7 & - & 4.1 & 2.5 & 1.2 & 3.1 & 2.2 \\
\hline Elemicin & 1558 & 15.4 & 74.9 & 54.8 & 5.7 & 69.8 & 36.2 & 4.1 & 37.9 & 17.6 \\
\hline Spathulenol & 1577 & 1.0 & 2.8 & 1.9 & - & 9.8 & 3.0 & $\operatorname{tr}$ & 0.4 & 0.2 \\
\hline$\beta$-Copaen-4- $\alpha$-ol & 1583 & 2.0 & 9.0 & 4.7 & - & 20.7 & 8.8 & $\operatorname{tr}$ & 0.3 & 0.1 \\
\hline \% Identification & & & & 98.7 & & & 95.0 & & & 96.9 \\
\hline \multicolumn{11}{|l|}{ Grouped components } \\
\hline Monoterpene hydrocarbons & & & & 0.1 & & & 0.4 & & & 0.3 \\
\hline Sesquiterpene hydrocarbons & & & & 28.9 & & & 43.0 & & & 75.2 \\
\hline Oxygen-containing sesquiterpenes & & & & 6.6 & & & 11.8 & & & 0.3 \\
\hline Phenylpropanoids & & & & 63.1 & & & 39.8 & & & 21.1 \\
\hline
\end{tabular}

RI - Retention index; (-) absence of substance; tr - traces $(\leq 0.05)$.

a Average of substances in the twenty accessions of each population.

(Fig. 5). The cluster C, formed only by accessions of the Piquete population, was mainly characterized by the high content of germacrene D, trans- $\alpha$-bergamoteme, and bicyclogermacrene (Fig. 6). Cluster D consists of 36 accessions from both population of Adrianópolis and Iporanga, approximately $60 \%$ of the samples, it was characterized by high elemicin content, $\beta$-selinene, $\beta$-copaen-4$\alpha$-ol, biclyclogermacrene, germacrene $\mathrm{D}$, and trans-caryophyllene. The variation of the elemicin content $(4.1-37.9 \%$, Table 3$)$ was primarily responsible for collation of subsets (c-e) of the cluster C. While to cluster D elimicin was responsible (5.7-74.9\%, Table 3 ) for grouped the accessions of subsets $a$ and $b$.

The elemicin is considered a topical analgesic (patent no. WO 2013133723 A1) (Grange and James, 2013) and the natural herbicide (patent no. KR 2007932867) (Kim et al., 2007). Thus, the essential oils of these populations, especially from Adrianópolis and Iporanga, represent an important source for obtaining elim- icin that has potential for application in dental uses, veterinary or pharmaceutical formulations, and development of new herbicides.

According to Roberts et al. (1996), the production of secondary metabolites results from complex interactions among biosynthesis, transport, storage and degradation. Each of the afore mentioned processes is, in turn, controlled by genes; therefore, the chemical composition of essential oils is influenced by three main factors: heredity, ontogeny (developmental stage), and environment. However, in this study, in addition to the above factors, another factor that must be taken into consideration is the origin of the accessions of $O$. selloi, which were collected from different geographical regions (Fig. 1). There are countless examples of occurrence of geographical variations in the production and composition of volatile (Miguel et al., 2015; Pateira et al., 1999; Santos et al., 2002, 2005). Such differences in the chemical composition of the essential oils

Table 4

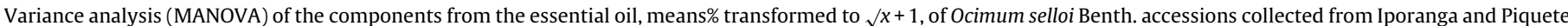
(SP), and Adrianópolis (PR).

\begin{tabular}{|c|c|c|c|c|}
\hline Compounds & Iporanga (\%) & Adrianópolis (\%) & Piquete (\%) & RI \\
\hline Methyl chavicol & $1.4 \pm 0.3 \mathrm{a}$ & $1.2 \pm 0.3 \mathrm{a}$ & $1.0 \pm 0.6 a$ & 1197 \\
\hline trans-Anethole & $1.3 \pm 0.2 \mathrm{a}$ & $1.1 \pm 0.2 \mathrm{a}$ & $1.0 \pm 0.4 \mathrm{a}$ & 1283 \\
\hline Methyl eugenol & $1.5 \pm 0.3 \mathrm{a}$ & $1.0 \pm 0.3 \mathrm{a}$ & $1.3 \pm 0.6 \mathrm{a}$ & 1403 \\
\hline trans-Caryophyllene & $1.8 \pm 0.1 c$ & $2.6 \pm 0.1 \mathrm{a}$ & $2.2 \pm 0.2 \mathrm{~b}$ & 1419 \\
\hline trans- $\alpha$-Bergamotene & $1.6 \pm 0.1 b$ & $1.3 \pm 0.1 b$ & $4.2 \pm 0.2 \mathrm{a}$ & 1436 \\
\hline Germacrene D & $2.6 \pm 0.2 b$ & $2.9 \pm 0.2 b$ & $5.3 \pm 0.3 \mathrm{a}$ & 1480 \\
\hline$\beta$-Selinene & $2.9 \pm 0.2 \mathrm{~b}$ & $3.5 \pm 0.2 \mathrm{a}$ & $1.9 \pm 0.4 \mathrm{c}$ & 1487 \\
\hline Bicyclogermacrene & $2.3 \pm 0.1 c$ & $2.9 \pm 0.1 b$ & $4.0 \pm 0.3 \mathrm{a}$ & 1495 \\
\hline$(E, E)$ - $\alpha$-Farnesene & $1.5 \pm 0.1 \mathrm{~b}$ & $1.8 \pm 0.1 \mathrm{a}$ & $1.8 \pm 0.2 \mathrm{a}$ & 1508 \\
\hline Elemicin & $7.5 \pm 0.3 a$ & $5.8 \pm 0.3 b$ & $4.1 \pm 0.7 \mathrm{c}$ & 1558 \\
\hline$\beta$-Copaen-4- $\alpha$-ol & $2.4 \pm 0.1 \mathrm{~b}$ & $3.2 \pm 0.1 \mathrm{a}$ & $1.0 \pm 0.3 c$ & 1583 \\
\hline
\end{tabular}

Average scores (mean \pm SE mean) in the same line with the same letters are not significantly different $(P<0.05)$. RI $($ Retention index). 


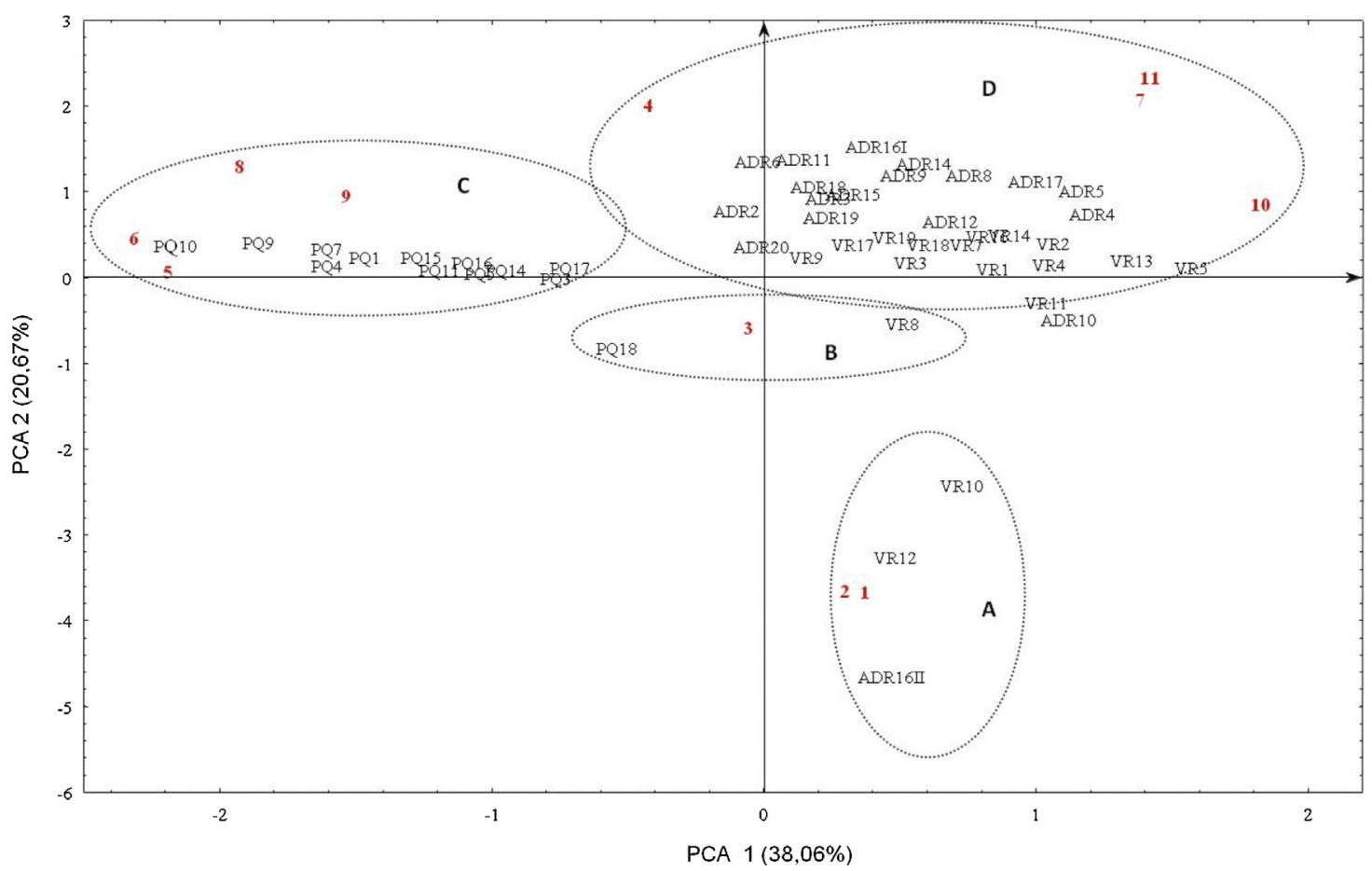

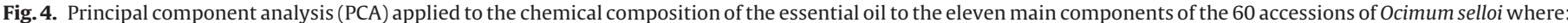

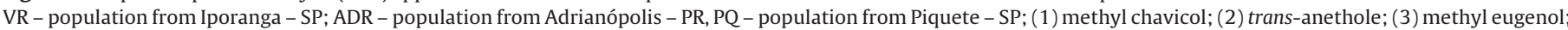
(4) trans-caryophyllene; (5) trans- $\alpha$-bergamotene; (6) germacrene D; (7) $\beta$-selinene, (8) bicyclogermacrene; (9) (E,E)- $\alpha$-farnesene, (10) elemicin; (11) $\beta$-copaen-4- $\alpha$-ol.

of different species in different origins may reflect the different environmental conditions of each particular site and growing conditions (different altitudes, different sun exposure, different soil type, etc.) (Figueiredo et al., 2008). In the present work, both the environment and genetic factors had influence on the chemical composition of the essential oils, but the comparison of the data of chemical analysis and molecular markers indisputably shows the importance of the genetic factor in major differences, as shown in the Figs. 3 and 4, where there are group, in each, containing accessions of Piquete.

The same influence of genetic factors occurs in other groups containing accessions of Iporanga and Adrianópolis, which is rea-

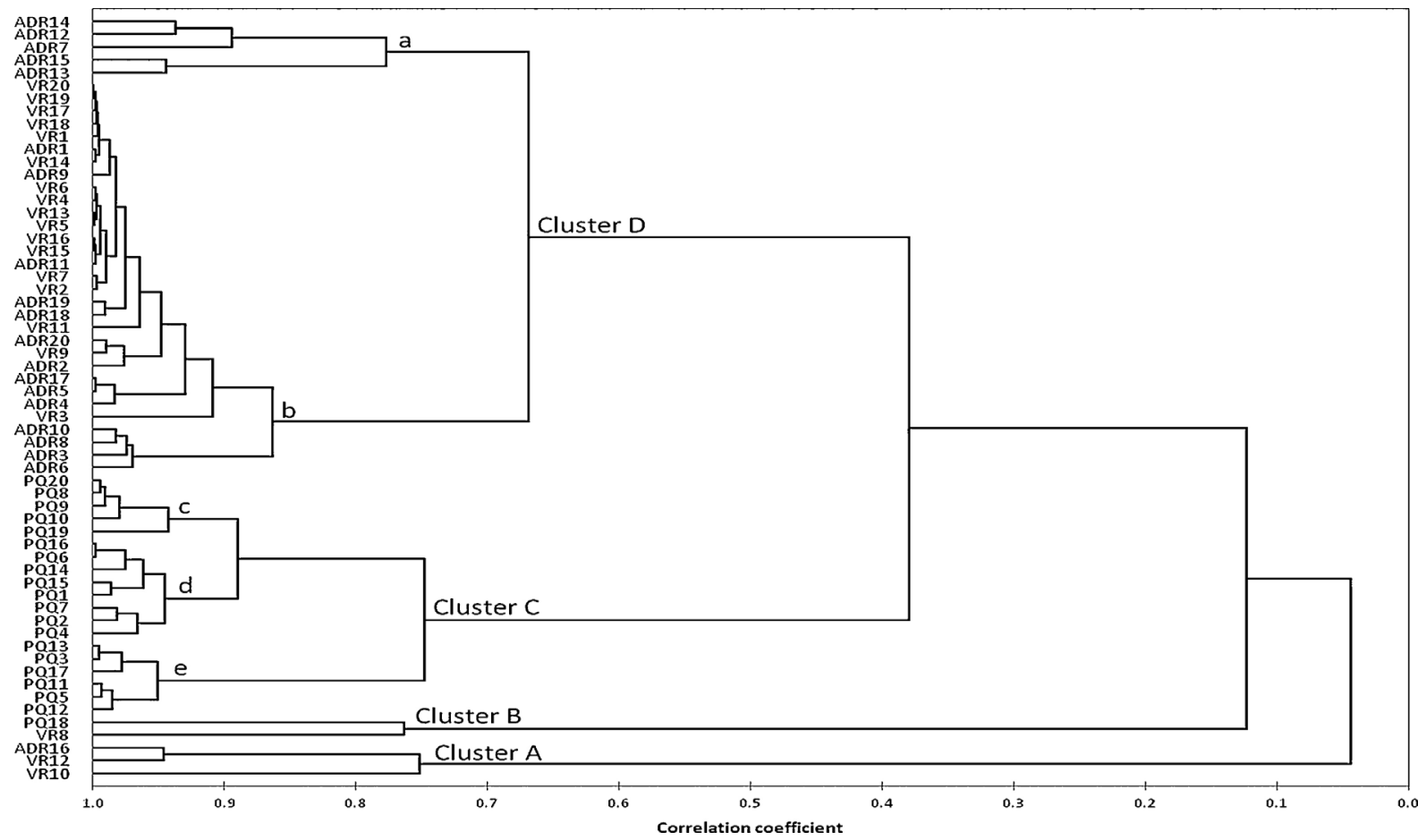

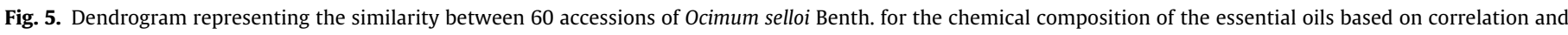
using unweighted pair-group method with arithmetic average(UPGMA). Accessions: ADR (Adrianópolis), VR (Iporanga), PQ(Piquete). 

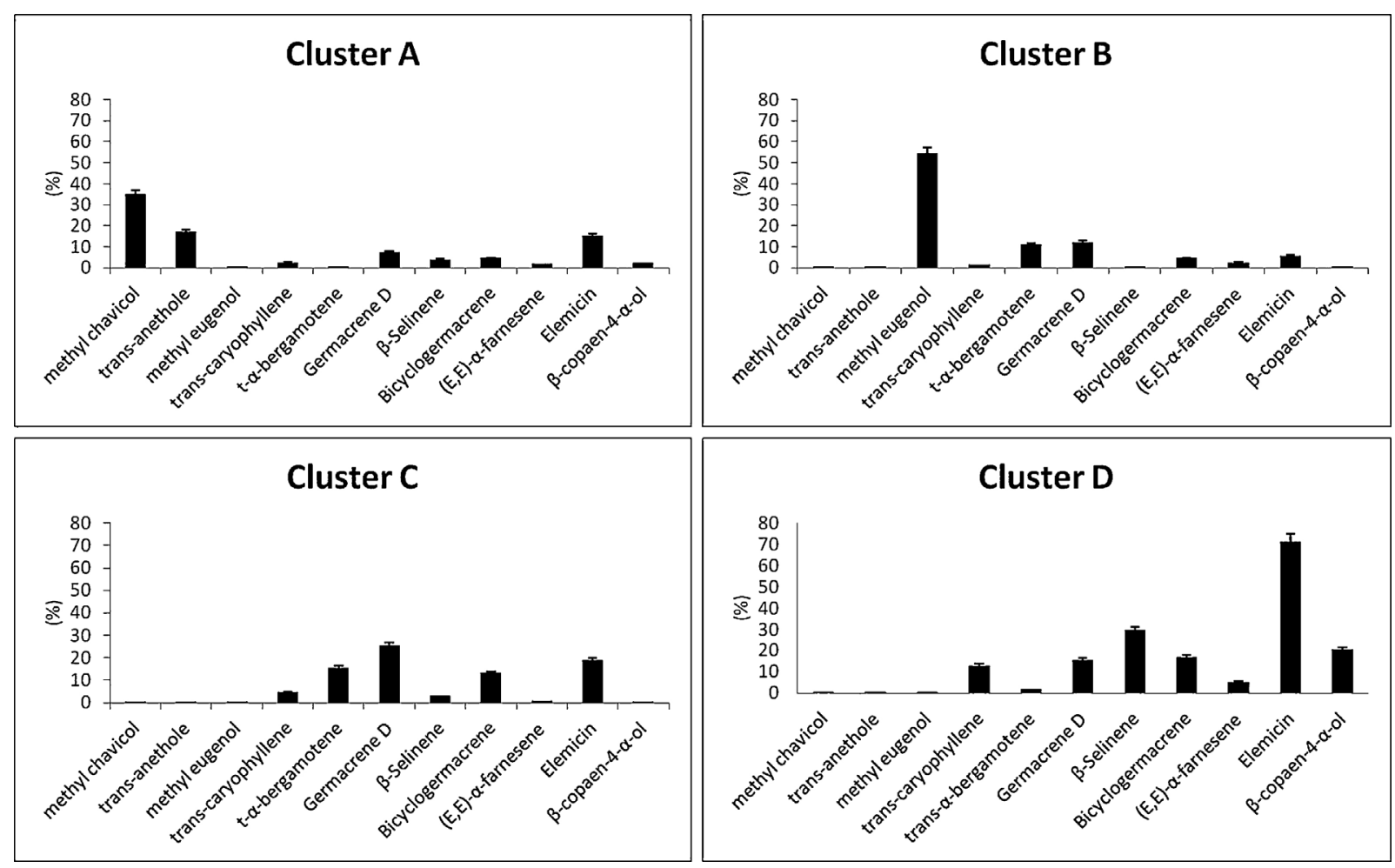

Fig. 6. Means of the 11 most important chemical constituents of the essential oils of clusters A-D of Ocimum selloi (vertical lines show \pm SEM).

sonable for being nearby regions allowing gene flow between populations.

\section{Conclusion}

The results from the investigation of the chemical and genetic diversity in three populations of $O$. selloi have revealed a strong genetic structure among the evaluated populations, probably due to distinct selective pressures, reproductive system and geographic distribution. These results are important for conservation and preservation of the species, also for genetic improvement programs and use of essential oils for commercial application. The genetic distances obtained were confirmed by the differences found in the chemical profile of the plants. Therefore, it demonstrated an agreement between the chemical and molecular characterization in the clustering of $O$. selloi Benth. of accessions from three distinct regions. The essential oil shows potential for the manufacture of products for veterinary, pharmaceutical, and agricultural use.

\section{Acknowledgments}

Acknowledgments to Fundação de Apoio à Pesquisa do Estado de São Paulo (FAPESP) for financial support to research (2002/140050 ). Roselaine Facanali thanks the Coordenação de Aperfeiçoamento de Pessoal de Nível Superior (CAPES) by MD and Ph. D fellowships.

\section{References}

Adams, R.P., 2001. Identification of Essential Oil Components by Gas Chromatography/Mass Spectroscopy. Allured Publishing Co., Carol Stream, Illinois.

Amaral, C.L.F., Casali, V.W.D., 2000. Identification and characterization of two populations of basil (Ocimum selloi Benth.) with isoenzymic markers. Rev. Bras. Plant. Med. 2, 9-15.

Brasileiro, B.P., Amaral, C.L.F., 2007. Caracterização do sistema reprodutivo de acessos de Ocimum spp. (Lamiaceae) do banco de germoplasma de plantas medicinais da UESB - Bahia, Brasil. Magistra 19 (4), 333-336.
Carović-Stanko, K., Liber, Z., Besendorfer, V., Javornik, B., Bohanec, B., Kolak, I., Satovic, Z., 2010. Genetic relations among basil taxa (Ocimum L.) based on molecular markers, nuclear DNA content, and chromosome number. Plant Syst. Evol. 285, 13-22.

CEPAGRI/UNICAMP, 2013. <http://www.cepagri.unicamp.br/outras-informacoes/ clima-dos-municipios-paulistas.html/> (accessed 14.10.13.).

Chen, S., Dai, T., Chang, Y., Wang, S., Ou, S., Chuang, W., Cheng, C., Lin, Y., Lin, L., Kul, H., 2013. Genetic diversity among Ocimum species based on ISSR, RAPD and SRAP markers. Aust. J. Crop Sci. 7 (10), 1463-1471.

Chikkaswamy, B.K., Prasad, M.P., Chandrashekharaiah, K.S., 2013. Detection of genetic diversity in Ocimum species using RAPD markers. Int. J. Res. Pharm. Sci. 4 (1), 58-64.

Coelho, A.S.G., 2001. Bood-P: Avaliação de dendrogramas baseados em estimativas de distâncias/similaridades genéticas através do procedimento de bootstrap, Versão 3.0 (Software). UFG, Goiânia.

Craveiro, A.A., Fernandes, A.G., Andrade, C.H.S., Matos, F.J.A., Alencar, J.W., Machado, M.I.L., 1981. Óleos essenciais de plantas do Nordeste, Ed. da UFC, Fortaleza/CE.

Excoffier, L., Smouse, P.E., Quattro, J.M., 1992. Analysis of molecular variance inferred from metric distances among DNA haplotypes: application to human mitochondrial DNA restriction data. Genetics 131 (2), 479-491.

Facanali, R., Campos, M.M.S., Pocius, O., Ming, L.C., Soares-Scott, M.D., Marques, M.O.M., 2009. Reproductive biology of Ocimum selloi Benth. populations. Rev. Bras. Plant. Med. 11 (2), 141-146.

Figueiredo, A.C., Barroso, J.G., Pedro, L.G., Scheffer, J.J.C., 2008. Factors affecting secondary metabolite production in plants: volatile components and essential oils. Flavour Fragr. J. 23, 213-226.

Franca, C.S., Menezes, F.S., Costa, L.C.B., Niculau, E.S., Alves, P.B., Pinto, J.E.B., Marcal R.M., 2008. Analgesic and antidiarrheal properties of Ocimum selloi essential oil in mice. Fitoterapia 79, 569-573.

Gaia, J.M.D., Mota, M.G.C., Conceição, C.C.C., Costa, M.R., Maia, J.G.S., 2004. Similaridade genética de populações naturais de pimenta-de-macaco por análise RAPD. Hortic. Bras. 22 (4), 686-689.

Ganiyu, O., 2008. Antioxidative potential of Ocimum gratissimum and Ocimum canum leaf polyphenols and protective effects on some pro-oxidants induced lipid peroxidation in rat brain: an in vitro study. Am. J. Food Technol. 3 (5), 325-334.

Gauer, L., Cavalli-Molina, S., 2000. Genetic variation in natural population of mate (Ilex paraguariensis A. St. -Hil., Aquifoliaceae) using RAPD markers. Heredity 84, 647-656.

Gomes Filho, A., Oliveira, J.G., Viana, A.P., Siqueira de, A.P.O., Oliveira, M.G., Pereira, M.G., 2010. RAPD molecular markers and morphological descriptors in assessing the genetic diversity of guava (Psidium guajava L.). Acta Sci. Agron. 32 (4), 627-633.

Grange, L., James, M., 2013. Synthesis of elemicin and topical analgesic compositions thereof. PCT Int. Appl., Patent no. WO 2013133723 A1 12 Sept 2013. 
Harisaranraj, R., Prasitha, R., Saravana Babu, S., Suresh, K., 2008. Analysis of inter-species relationships of Ocimum species using RAPD markers. Ethnobot. Leaflets 12, 609-613.

Kim, M.S., Lee, Y.S., Kim, H.Y., Choi, H.J., Heo, S.J., Kwon, S.B., Lim, S.H., Kim, K.H., Kim, S.M., 2007. By; Kangwon Province, S. Korea. KNU-Industry Cooperation Foundation, assignee. Novel herbicidal substance, elemicin, purified from Asarum sieboldii miq. having new chemical structure, and preparation method thereof. Repub. Korean Kongkae Taeho Kongbo, Patent no. KR 2007032867 A 20 Sept 2005

Loveless, M.D., Hamrick, J.L., 1984. Ecological determinants of genetic structure in plant populations. Annu. Ver. Ecol. Syst. 15, 65-95.

Martins, E.R., 1998. Estudos em Ocimum selloi Benth isozimas, morfologia e óleo essencial. In: Ming, L.C., Scheffer, M.C., Corrêa-junior, C., Barros, I.B.I., Mattos, J.K.A. (Eds.), Plantas Medicinais, Aromáticas e Condimentares: Avanços na Pesquisa Agronômica, vol. 2, pp. 97-125.

Mclafferty, F.W., Stauffer, D., 1989. The Wiley/NBS Registry of Mass Spectral Data, vol. 1-6. Jonh Wiley Sons, New York.

Mentz, L.A., Lutzemberger, L.C., Schenkel, E.P., 1997. Da flora medicinal do Rio Grande Do Sul: notas sobre a obra de D’Ávila (1910). Cad. Farm. 13 (1), 25-48.

Miguel, M.G., Duarte, J., Figueiredo, A.C., Barroso, L.G., Pedro, L.G., 2015. Thymus carnosus Boiss.: effect of harvesting period, collection site and type of plant material on essential oil composition. J. Essent. Oil Res. 17, 422-426.

Moraes, L.A.S., Facanali, R., Marques, M.O.M., Ming, L.C., Meireles, M.A.A., 2002. Phytochemical characterization of essential oil from Ocimum selloi. An. Acad. Bras. Cienc. 74 (1), 183-186.

Morais, L.A.S., 2003. Adubação e sazonalidade na produção de fitomassa, metodologia de extração, rendimento e qualidade do óleo essencial de Ocimum selloi Benth. $250 \mathrm{f}$. Tese (doutorado) -Universidade Estadual Paulista. Faculdade de Ciências Agronômicas de Botucatu. <http://hdl.handle.net 11449/103272/> (accessed 06.05.15.)

Nascimento, J.C., Barbosa, L.C.A., Paula, V.F., David, J.M., Fontana, R., Silva, L.A.M., França, R.S., 2011. Chemical composition and antimicrobial activity of essential oils of Ocimum canum Sims. and Ocimum selloi Benth. An. Acad. Bras. Cienc. 83 (3), 787-799.

Nodari, R.O., Guerra, M.P., 2001. Aspectos genéticos e moleculares da produção vegetal. In: Simões, C.M.O., Schenkel, E.P., Gosmann, G., Melo, J.C.P., Mentz, L.A Petrovick, P.R. (Eds.), Farmacognosia: Da Planta ao Medicamento. Universidade UFRGS/UFSC, Porto Alegre/Florianópolis, pp. 29-44.

Pateira, L., Nogueira, T., Antunes, A., Venâncio, R., Tavares, J.C., 1999. Two chemotypes of Crithmum maritimum L. from Portugal. Flavour Fragr. J. 14, 333-343.

Paula de, J.P., Gomes-Carneiro, M.R., Paumgartten, F.J.R., 2003. Chemical composition, toxicity and mosquito repellency of Ocimum selloi oil. J. Ethnopharmacol. 88 (2-3), 253-260.

Pessanha de, P.G.O., Viana, A.P., Amaral Júnior, A.T., Souza, R.M., Teixeira, M.C., Pereira, M.G., 2011. Avaliação da diversidade genética em acessos de Psidium ssp. via marcadores RAPD. Rev. Bras. Frutic. 33 (1), 129-136.

Pianowsky, L.F., 2005. Cordia verbenacea: planta contra a inflamação. J. Phytom. 5 $1-3$

Pluhár, Z., Kocsis, M., Kuczmog, A., Csete, S., Simkó, H., Sárosi, S., Molnár, P., Horváth, G., 2012. Essential oil composition and preliminary molecular study of four Hungarian Thymus species. Acta Biol. Hung. 63 (1), 81-96.
Roberts, J.E., Speedie, M.K., Tyler, V.E., 1996. Pharmacognose and Pharmacobiotechnology. Williams \& Wilkins, Baltimore, pp. 337. Rohlf, F.J., 2000. NTSYS-pc: Numerical Taxonomy and Multivariate Analysis System. Applied Biostatistics, New York.

Santos, P.A.G., Barroso, J.G., Figueiredo, A.C., Pedro, L.G., Salgueiro, L.R., Fontinha, S.S., Deans, S.G., Scheffer, J.J.C., 2005. Chemical polymorphism of populations of Thymus caespititius grown on the islands Corvo, Flores, São Miguel and Terceira (Azores) and on Madeira assessed by analysis of their essential oils. Plant Sci. 169, 1112-1117.

Santos, P.A.G., Figueiredo, A.C., Barroso, J.G., Pedro, L.G., Deans, S.G., Scheffer, J.J.C., et al., 2002. Composition of the essential oils from populations of Crithmum maritimum L. grown on four Azorean islands. In: Rauter, A.P. (Ed.), Natural Products in the New Millennium: Prospects and Industrial Application, vol. 47. Kluwer Academic Publishers, The Netherlands, pp. 135-141.

Schmidt, J.A., 1858. Labiatae. In: Martius, K.F.P. (Ed.), Flora Brasiliensis: Enumerato Plantarum in Brasilia. Wheldon \& Wesley, New York, pp. 117-338.

Schneider, S., Roessli, D., Excoffier, L., 2000. Arlequin ver. 2000: A Software for Population Data Analysis. Geneva.

Silva, M.A.S., Ming, L.C., Pereira, A.M.S., Bertoni, B.W., Batistini, A.P., Pereira, P.S. 2006. Phytochemical and genetic variability of Casearia sylvestris Sw. from São Paulo state Atlantic forest and Cerrado populations. Rev. Bras. Plant. Med. 8, 159-166.

Silveira, D.G., Amorim, E.P., Jesus, O.N., Souza, F.V.D., Pestana, K.N., Santos, V.J., Santana, J.R.F., 2009. Genetic variability estimated among caroá populations through RAPD markers. Pesq. Agropec. Bras. 44 (3), 283-290.

Sneath, P.H.A., Sokal, R.R., 1973. Numerical Taxonomy: The Principles and Practice of Numerical Classification. Freeman, San Francisco, pp. 573.

Troconis-Torres, I.G., Rojas-López, M., Hernández-Rodríguez, C., Villa-Tanaca, L., Maldonado-Mendoza, I.E., Dorantes-Álvarez, L., Telles-Medina, D. Jaramillo-Flores, M.E., 2012. Biochemical and molecular analysis of some commercial samples of shilli peppers from Mexico. J. Biomed. Biotechnol., 1-11, http://dx.doi.org/10.1155/2012/873090

Vieira, R.F., Goldsbrough, P., Simon, J.E., 2003. Genetic diversity of basil (Ocimum spp.) based on RAPD markers. J. Am. Soc. Hortic. Sci. 128 (1), 94-99.

Vieira, R.F., Grayer, R.J., Paton, A., Simon, J.E., 2001. Genetic diversity of Ocimum gratissimum L. based on volatile oil constituents, flavonoids and RAPD markers. Biochem. Syst. Ecol. 29 (3), 287-304.

Wang, X.F., Zheng, H.Y., Zheng, W.H., Ao, C.Q., Jin, H.Y., Zhao, L.H., Li, N., Jia, L.R., 2011. RAPD-Based genetic diversities and correlation with morphological traits in Camellia (Theaceae) cultivars in China. Genet. Mol. Res. 10 (2), 849-859.

Welsh, J., McClelland, M., 1990. Fingerprinting genomes using PCR with arbitrary primers. Nucleic Acids Res. 18 (24), 7213-7218.

Williams, J.G.K., Kubelik, A.R.K., Livak, J.L., Rafasla, J.A., Tingey, S.V., 1990. DNA polymorphisms amplified by arbitrary primers are useful as genetic markers. Nucleic Acids Res. 18, 6531-6535.

Windholz, M. (Ed.), 1976, 9th ed. Merck \& Co.,Inc., Rahway, New Jersey.

Zucchi, M.I., Baldin, J.P., Chaves, L.J., Coelho, A.S.G., Couto, M.A., Morais, L.Z., Vencovsky, R., 2005. Genetic structure and gene flow of Eugenia dysenterica natural populations. Pesq. Agropec. Bras. 40, 975-980. 